\title{
Utilizing Vulnerability and Risk Indexes for Cultural Heritage in Yogyakarta and Central Java
}

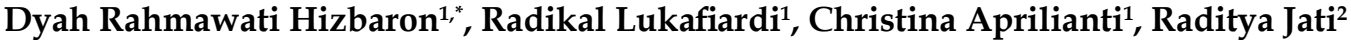 \\ ${ }^{1}$ Faculty of Geography, Universitas Gadjah Mada, Bulaksumur, Yogyakarta, Indonesia \\ ${ }^{2}$ National Disaster Management Agency, Republic of Indonesia, Jakarta, Indonesia \\ *) Corresponding Author (e-mail: dyah.hizbaron@geo.ugm.ac.id)
}

Received: 15 September 2020/ Accepted: 24 November 2020 / Published: 31 December 2020

\begin{abstract}
Indonesia is home to many cultural heritages which are exposed to natural disaster, its number has grown by $400 \%$ within the years of 1975-2010. In order to protect the cultural heritages, the national government released InaRisk - a web based geospatial data to identify risk information. This application, however, not fully apprises its users of the potential loss that cultural heritage objects, especially temples, may sustain. For these reasons, the research set out to evaluate the potential loss of temples by making use of disaster vulnerability and risk approaches. Seven temples were exposed to earthquake and landslide hazards; hence, observed as the research object on a micro-scale. The research method combined tabular, spatial, and temporal data of several indicators, namely types of building materials, building's structural integrity after earthquakes and landslides, the number of salvageable objects, building age, significance, historical value, and the number of visitors. The results showed that Prambanan and Sewu Temples had the most substantial amounts of potential losses incurred from damages to at-risk elements, namely the numbers of visitors, employees, and supporting facilities and their distances to sources of hazards. Assessing the numerical values of losses requires further improvements in accuracy as it has not thoroughly factored in the significance of the temples, which is composed of historical value, building age, number of visitors, and other components. Valuation of this significance is still limited to currently available data, including the price of the constituent rocks, area and volume, and supporting facilities.
\end{abstract}

Keywords: vulnerability, risk, cultural heritage, InaRisk, Yogyakarta

\section{Introduction}

The records of cultural heritage increase due to new discoveries. World bank records that the amounts of cultural heritage worldwide have soared by $400 \%$ since 1975 (Parisi \& Augenti, 2013). Especially in Indonesia, from 2013 until 2018, their total number in Indonesia increased to 129 units (Direktorat Pelestarian Cagar Budaya dan Permuseuman, 2016b). Around 96,400 units of cultural heritage are not yet official and still at the registration stage, while 49,007 units have been verified and are at the stage of recommendation; the latter has increased by 1,619 units over the last five years (Direktorat Pelestarian Cagar Budaya dan Permuseuman, 2016b).
Cultural heritage is one of the at-risk elements requiring thorough evaluation, even though such assessment is seemingly less urgent than that of settlements and other infrastructure (Romāo \& Paupério, 2019). Given their significant number and the two persistent threats to their existence, namely age and natural disasters (National Library of Indonesia, 2014), they must receive further attention in disaster management. The object of this research is parts of cultural heritage sites, namely temples. In order to protect the cultural heritages, the national government of Indonesia initiate a precautionary mechanism to identify level of risk using InaRisk.

InaRisk, a geospatial data-based risk information system provided by the 
Government of the Republic of Indonesia, contains information on types of hazards, the number of exposed populations, total losses, and potential disaster risks (Amri et al., 2018; $\mathrm{BNPB}, 2016)$. Users can access it through either the InaRisk website or the Android and IOSbased InaRisk Professional application. The details of the information stored here depend on to what extent the regencies/cities elaborate on the predefined disaster-prone areas. Hazard, vulnerability, and risk are described by regencies or cities (unit of analysis), or otherwise known as macro-scale data, and combined with exposed populations as the at-risk elements - i.e., a set of data available at the interlinked survey database organized by the Statistics Indonesia (BPS, 2020).

Based on the information displayed on InaRisk, users can access details on hazard, hazard class, and what to do before, during, and after disasters, but fewer particulars on vulnerability or risk classes. Therefore, to complete these details, the study was intended to evaluate the potential loss of cultural heritage temples using the disaster vulnerability and risk approach. It benefits and enriches the InaRisk information system, which, for the sake of completeness, has been improved by continuously adding new data. Unfortunately, the element at risk of cultural heritage have not yet fully incorporated into InaRisk.

Vulnerability is an essential aspect of InaRisk. This research highlights a problem in the Special Region of Yogyakarta, that is, the paucity of data related to cultural heritage vulnerability. Vulnerability and risk maps are vital in the search for proper countermeasures for cultural heritage objects that are experiencing irreversible damages over time (Wang, 2015). The research aims to evaluate the potential loss of temples by making use of disaster vulnerability and risk approaches. In this study, hazards are evaluated as potential threats to temples with a micro-scale approach, i.e., using a detailed observation scale, 1:10,000. InaRisk provides disaster risk information on a macro scale, 1:250,000, that covers a vast spatial scope because its system is intended to accommodate national needs.

\section{Literature Review}

The cultural heritage is a comprehensive concept. UNESCO defines it as cultural heritage sites, historic cities, cultural landscapes, sacred natural sites, underwater cultural heritage, museums, movable cultural heritage, handicrafts, digital heritage documentation, cinematographic heritage, oral traditions, languages, festivals, crafts, religions and beliefs, music and songs, performance arts, traditional medicines, literature, traditional culinary delights, and traditional sports (ICCROM; ICOMOS; IUCN; UNESCO World Heritage Centre, 2010). Cultural heritage or heritage is the product of interactions between social and natural systems comprising infinite physical and social values exposed to changes brought about by time and disasters (Spennemann, 2007). It can be classified into five, namely cultural heritage objects, cultural heritage buildings, cultural heritage structures, cultural heritage sites, and cultural heritage areas.

The research puts cultural heritage within the framework of disaster risk reduction. That being said, hazard, vulnerability, and risk analyses are required to protect cultural heritage from further irreversible impact. The vulnerability and disaster risk analysis of cultural heritage in this study uses spatial and temporal approaches (Wang, 2015). Previous research or literature relevant to this theme has been reviewed extensively, although not specific to Indonesia (Table 1).

As described in Table 1, cultural heritage management in many counties has incorporated disaster context. This topic has been widely studied to understand not only the effect of time (age) as the sole threat, but that cultural heritage is also increasingly exposed to natural hazards. Also, the approaches used in relevant studies are widely diverse, ranging from quantitative approaches (i.e., economic valuation, engineering structures of buildings, the spatial distribution of cultural heritage, and multi-stakeholder involvement) to qualitative approaches concentrating on the use of language in finding meaning in daily life (see Figure 1). 
Table 1. Literature review from previous research.

\begin{tabular}{|c|c|c|c|c|}
\hline No. & Research Objectives & Research Methods & Results & Sources \\
\hline 1 & $\begin{array}{l}\text { To analyze the } \\
\text { significance of } \\
\text { protecting cultural } \\
\text { heritage at the stage of } \\
\text { disaster response }\end{array}$ & $\begin{array}{l}\text { Qualitative (literature } \\
\text { review) }\end{array}$ & $\begin{array}{l}\text { Cultural heritage possesses social } \\
\text { values that are likely threatened } \\
\text { by various types of hazards, so } \\
\text { that a regulatory mechanism } \\
\text { is needed during emergency } \\
\text { response }\end{array}$ & $\begin{array}{l}\text { (Spennemann } \\
\text { \& Graham, } \\
\text { 2007) }\end{array}$ \\
\hline 2 & $\begin{array}{l}\text { To analyze potential } \\
\text { physical damages to } \\
\text { cultural objects due to } \\
\text { earthquake hazards in } \\
\text { Italy }\end{array}$ & $\begin{array}{l}\text { Quantitative (a study } \\
\text { of building's physical } \\
\text { structure) }\end{array}$ & $\begin{array}{l}\text { The type of building structure, } \\
\text { material quality, building } \\
\text { network and flexibility, and type } \\
\text { of structural irregularity, and } \\
\text { ease of retrofit are found to be } \\
\text { indicators that can accommodate } \\
\text { building damage assessment in } \\
\text { case of earthquakes. }\end{array}$ & $\begin{array}{l}\text { (Parisi \& } \\
\text { Augenti, 2013) }\end{array}$ \\
\hline 3 & $\begin{array}{l}\text { To identify at-risk } \\
\text { elements of cultural } \\
\text { heritage in a post- } \\
\text { disaster context in } \\
\text { Aceh, Indonesia }\end{array}$ & $\begin{array}{l}\text { Qualitative (linguistic } \\
\text { study) }\end{array}$ & $\begin{array}{l}\text { Distinguishing between heritage } \\
\text { that has been defined before } \\
\text { disasters and the one formed as a } \\
\text { result of disasters is challenging, } \\
\text { particularly because of linguistic } \\
\text { constraints in defining the } \\
\text { significance of heritage. }\end{array}$ & (Rico, 2014) \\
\hline 4 & $\begin{array}{l}\text { To analyze the risk } \\
\text { of cultural heritage } \\
\text { in Taiwan using } \\
\text { spatial and temporal } \\
\text { approaches }\end{array}$ & $\begin{array}{l}\text { Quantitative (area } \\
\text { study) }\end{array}$ & $\begin{array}{l}\text { The distribution and level of risks } \\
\text { of cultural heritage in the context } \\
\text { of climate change phenomena can } \\
\text { be identified by making use of } \\
\text { several threat scenarios. }\end{array}$ & (Wang, 2015) \\
\hline 5 & $\begin{array}{l}\text { To identify studies } \\
\text { concentrating on } \\
\text { structural mitigation } \\
\text { of cultural heritage in } \\
\text { case of fire }\end{array}$ & $\begin{array}{l}\text { Qualitative (review of } \\
\text { studies focusing on fire } \\
\text { risk reduction as an } \\
\text { approach) }\end{array}$ & $\begin{array}{l}\text { Two types of structural } \\
\text { mitigation approaches have } \\
\text { been applied to cultural heritage } \\
\text { exposed to fire hazards. }\end{array}$ & (Marrion, 2016) \\
\hline 6 & $\begin{array}{l}\text { To analyze total loss } \\
\text { (direct impact) of } \\
\text { cultural heritage due } \\
\text { to the earthquakes in } \\
\text { Spain }\end{array}$ & $\begin{array}{l}\text { Quantitative (economic } \\
\text { valuation) }\end{array}$ & $\begin{array}{l}\text { Determinants of total loss in } \\
\text { monetary units are adjusted to } \\
\text { the data available in a country. }\end{array}$ & $\begin{array}{l}\text { (Romāo \& } \\
\text { Paupério, 2019) }\end{array}$ \\
\hline 7 & $\begin{array}{l}\text { To evaluate } \\
\text { whether or not } \\
\text { the early warning } \\
\text { system installed or } \\
\text { developed for cultural } \\
\text { heritage facilitates } \\
\text { communication } \\
\text { between stakeholders } \\
\text { in Brazil }\end{array}$ & $\begin{array}{l}\text { Quantitative } \\
\text { and Qualitative } \\
\text { (participatory mapping) }\end{array}$ & $\begin{array}{l}\text { Coordination between cultural } \\
\text { heritage stakeholders is rather } \\
\text { poor; the early warning system } \\
\text { still needs to establish geo- } \\
\text { reference databases, expand } \\
\text { access to data, and improve } \\
\text { information dissemination. }\end{array}$ & $\begin{array}{l}\text { (Marchezini et } \\
\text { al., 2020) }\end{array}$ \\
\hline
\end{tabular}

Source: (Marchezini et al., 2020; Marrion, 2016; Parisi \& Augenti, 2013; Rico, 2014; Romāo \& Paupério, 2019; Spennemann \& Graham, 2007; Wang, 2015)

Disasterriskreductionaimstoprovideearly warning information related to potential losses (risk) and potential damage (vulnerability) caused by existing threats. Vulnerable buildings are characterized by a condition that causes them to be potentially damaged or affected by natural threats (Hizbaron et al.,
2018; UNISDR, 2009). The crucial primary input to vulnerability analysis is the availability of supporting data, particularly those on hazard levels. Vulnerability is calculated using a scale of 0 to 1 , which represents to what extent damages may arise from disasters. Scale 0 indicates no potential damage, while 1 shows 
maximum potential for damage. Parameters of vulnerability in this study are broadly clustered into three: (1) physical Vulnerability of Cultural Heritage Sites includes the number and existing condition of the main building at these sites and is a function of exposure and sensitivity; (2) the Vulnerability of Supporting Elements at Cultural Heritage Sites includes the number of supporting/public facilities located at these sites; (3) Social Vulnerability of Cultural Heritage Sites includes the number of employees and visitors at these sites.

The variables used to assess the vulnerability and risk of cultural heritage include the type of building structure, the quality of material used, building network and flexibility, type of structural irregularity, and ease of retrofit (Parisi \& Augenti, 2013). Another opinion states that these disaster aspects are measurable from stakeholder involvement, the understanding of term use, and the economic valuation of cultural heritage (Marchezini et al., 2020). A part from the diversity of vulnerability and risk variables, the availability of hazard data is also necessary because they act as the primary input to various scenarios (Wang,
2015). The availability of variables in Indonesia certainly has its uniqueness, as represented by existing data access.

\section{Research Method}

The research started with identifying temples exposed to earthquake hazards and their secondary effects, such as landslides, in Yogyakarta. At least seven temples fulfill this category, namely Sewu, Bubrah, Lumbung, Ghana, Ratu Boko Site, Prambanan, and Ijo. These temples were selected by taking their geomorphological positions into account and, thus, can be differentiated into two units: temples in alluvial plans and temples on structural hills. Alluvial plains have loose constituent materials, allowing vibration to propagate more intensively than structural hills that are composed of dense and compact materials. Accordingly, temples located in the former are more exposed to earthquakes compared to the ones on the latter. Structural hills, however, are susceptible to landslides or mass movements, which can also take place as the secondary effects of earthquakes (see Figure 2).

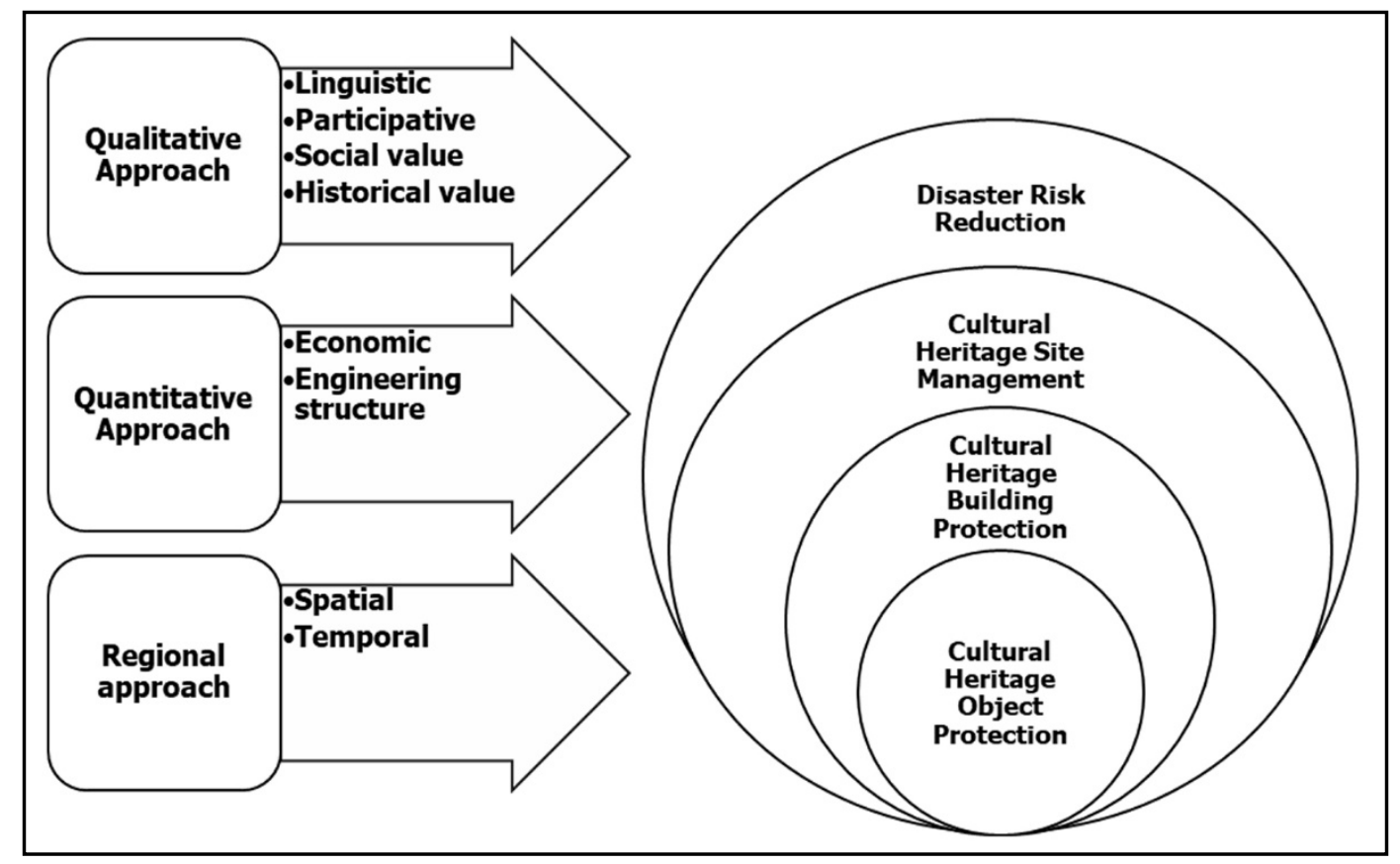

Figure 1. Research framework. 


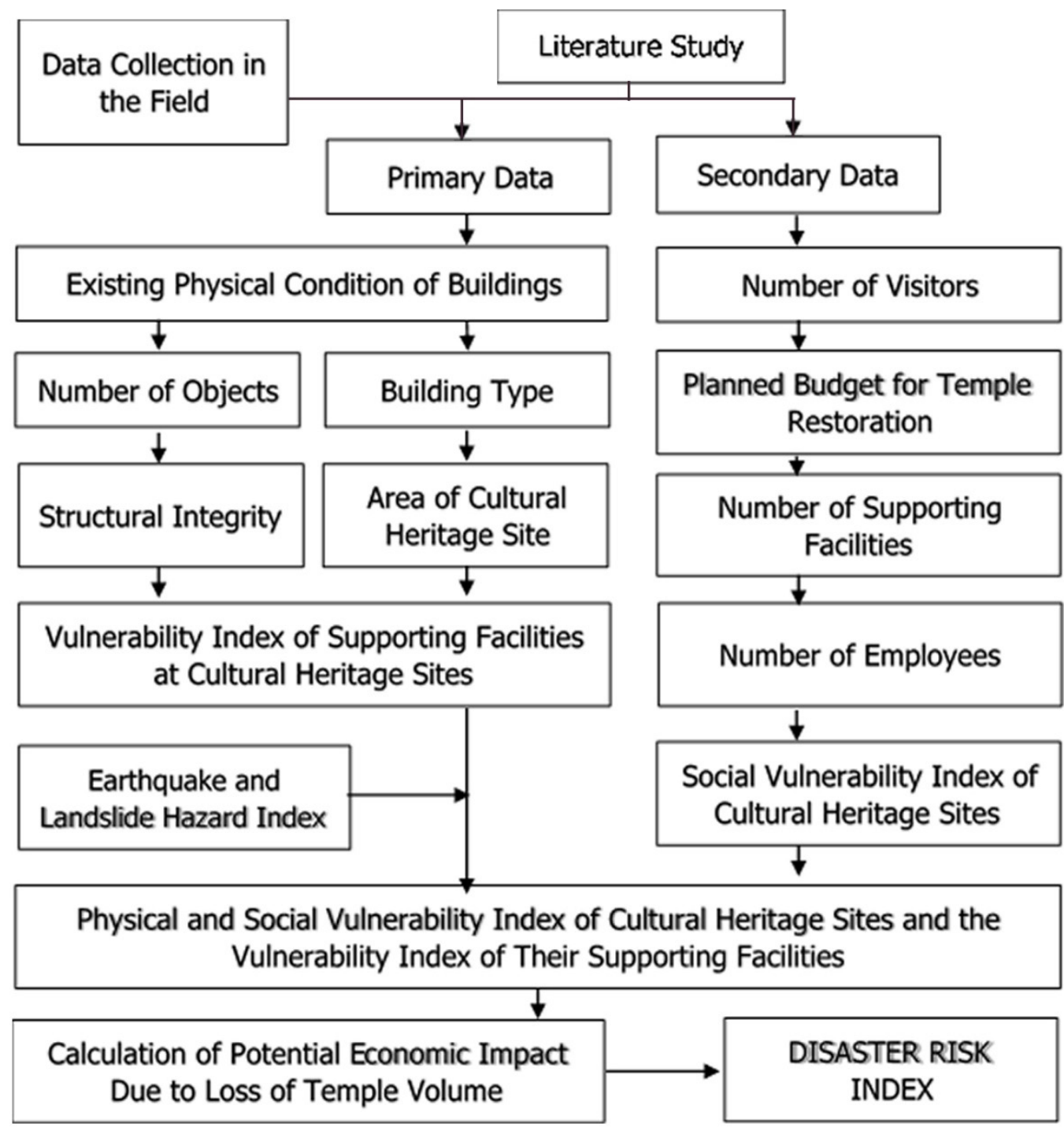

Figure 2. Research Flowchart.

This study focuses on temples as cultural heritage areas, and in the calculation of their vulnerability, it paid attention to variables such (1) cultural objects (randomly selected from various cultural objects in a cultural heritage area) and (2) cultural buildings (selected by purposive randomly sampling from the population of cultural buildings located within a cultural heritage area). The vulnerability index of cultural heritage sites in this activity was divided into three, namely (1) physical vulnerability (indicators were building type, area, structural integrity, and the number of objects at the sites), (2) vulnerability of supporting elements (based on the number of public/supporting facilities at the sites), and (3) social vulnerability (measured from the number of visitors and employees at the sites). Figure 2 shows the research method referred to in this study. Figure 2 describes the flow of methods or procedures carried out in this research. It started with a field survey to determine the locations of the measurement points, measurement of the cultural heritage area, object inventory inside the area, then continued to the random selection of the cultural objects for vulnerability and risk assessment. Afterward, the secondary data were collected from statistical figures and direct interviews with cultural heritage stakeholders, and then all research data were processed and analyzed in ILWIS 3.3 program to determine vulnerability scales (ranging between 0 and 1). Finally, vulnerability classes were adjusted to the conditions listed in Table 2. 
Table 2. Scale of Vulnerability Classes.

\begin{tabular}{|c|c|c|c|}
\hline No. & $\begin{array}{c}\text { Vulnerability } \\
\text { Classes }\end{array}$ & Index Values & Description \\
\hline 1 & I & $0.00<V \leq 0.20$ & $\begin{array}{l}\text { Very low vulnerability; earthquake and landslide } \\
\text { hazards have no significant impact. }\end{array}$ \\
\hline 2 & II & $0.21<V \leq 0.40$ & $\begin{array}{l}\text { Low vulnerability; the potential impact of earth- } \\
\text { quake and landslide hazards is tolerable. }\end{array}$ \\
\hline 3 & III & $0.41<V \leq 0.60$ & $\begin{array}{l}\text { Medium vulnerability; earthquake and landslide } \\
\text { hazards potentially create a fairly significant impact. }\end{array}$ \\
\hline 4 & IV & $0.61<V \leq 0.80$ & $\begin{array}{l}\text { Fairly high vulnerability; earthquake and landslide } \\
\text { hazards can severely affect the at-risk elements. }\end{array}$ \\
\hline 5 & $\mathrm{~V}$ & $0.81<V \leq 1.00$ & $\begin{array}{l}\text { High vulnerability; the potential impact of earth- } \\
\text { quake and landslide hazards is intolerable and } \\
\text { massive. }\end{array}$ \\
\hline
\end{tabular}

\section{Results}

\subsection{Hazards}

Potential hazard data inputted to the analysis were the outputs of several earthquake scenarios with 10- and 50-year return periods and a landslide scheme. Landslide hazards were determined based on landslide susceptibility without incorporating return period data like the earthquake hazard scenarios. Table 3 summarizes the distribution of the hazard index values of prior separate studies, while Figure 3 shows the spatial distribution of potential hazards.

\subsection{Vulnerability}

Based on the hazard index, this study evaluated the potential vulnerability of every selected temple using three scenarios. As provided in Table 4 below, the inputted data were adjusted to the available information in the field and secondary data. Multi-criteria analysis, which can manage as many datasets as desired, was used to process these inputs, each of which was weighted according to the scenario, e.g., for the physical vulnerability, all contributing physical factors were weighted higher than other indicators.

Vulnerability data analysis produced three types of indexes, namely physical vulnerability index, vulnerability index of the supporting facilities at the sites, and social vulnerability (Tables 5 and 6). The results showed that
Prambanan and Sewu Temples had high levels of physical vulnerability, as evident from the index values of 0.77 and 0.95 , respectively (Table 5). These figures were based on the scenarios built from a multi-criteria evaluation that used the supporting data and assigned a weight value to every indicator. This evaluation factored in data on potential hazards, and the scenarios produced consistent results, in which Prambanan and Sewu Temples had the highest vulnerability among the sites selected in this study. Gana Temple, for example, had a vulnerability index of 0.3 , meaning that the potential impact of earthquake and landslide hazards is tolerable. Compared to other sites, the reasons behind such low vulnerability index are the incomplete structure of the temple and a smaller total area.

In the scenario of vulnerability index based on supporting components, Prambanan Temple scored one and was thereby the most vulnerable. The high vulnerability was attributable to the presence of many supporting facilities, including four places of worship, four parking spaces, 13 restrooms, 11 gazebos, 604 souvenir shops, and four main offices, all of which were also potentially impacted, particularly in the event of earthquakes. More supporting facilities at a cultural heritage site mean that the functions of more objects are exposed to earthquake hazards, leading to high vulnerability. 
Table 3. Quantification of the hazard index values inputted to the research analysis.

\begin{tabular}{lccc}
\hline \multirow{2}{*}{ Cultural heritage } & \multicolumn{3}{c}{ Hazard Index } \\
\cline { 2 - 4 } & $\begin{array}{c}\text { Earthquakes with } \\
\text { 10-year return period }\end{array}$ & $\begin{array}{c}\text { Earthquakes with } \\
\text { 50-year return period }\end{array}$ & Landslides \\
\hline Sewu Temple & 0.096 & 0.947 & 0 \\
Bubrah Temple & 0.097 & 0.943 & 0 \\
Lumbung Temple & 0.099 & 0.941 & 0 \\
Prambanan Temple & 0.107 & 0.95 & 0 \\
Gana Temple & 0.088 & 0.923 & 0 \\
Ratu Boko Site & 0 & 0.478 & 0.67 \\
Ijo Temple & 0 & 0.364 & 0.67 \\
\hline
\end{tabular}

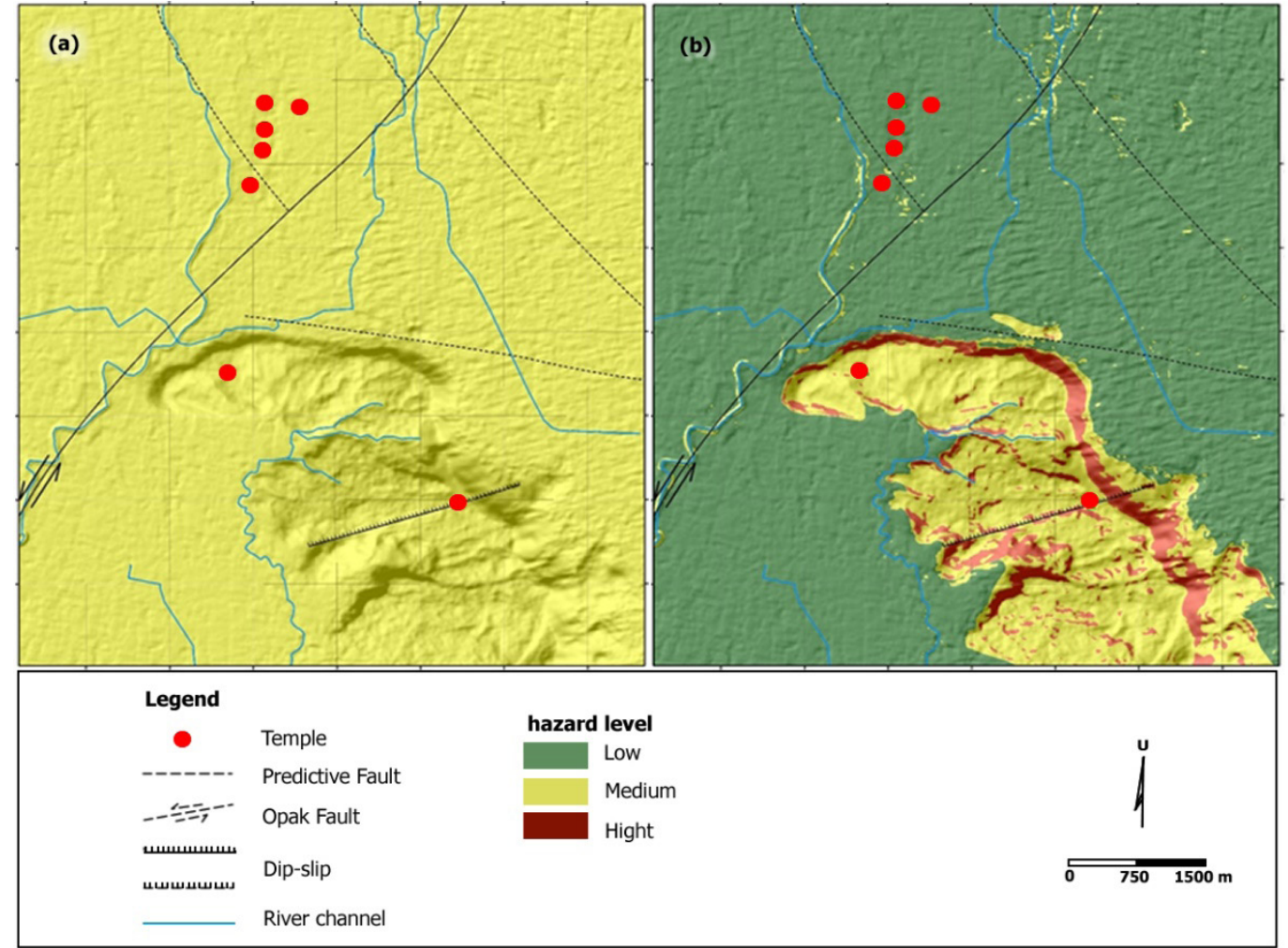

Figure 3. Earthquake Hazard Maps with 10-year Return Period Scenario (a) and Landslide Hazard Map (b). The resulting information was scaled at 1:25,000 (Source: research collaboration result between Faculty of Geography, Faculty of Engineering Geology Universitas Gadjah Mada, with BNPB, unpublished work 2019).

Table 4. Data (and units of measurement) and their effects on vulnerability.

\begin{tabular}{clll}
\hline No. & \multicolumn{1}{c}{ Data } & $\begin{array}{c}\text { Measurement } \\
\text { Units }\end{array}$ & \multicolumn{1}{c}{ Effects } \\
\hline 1 & $\begin{array}{l}\text { Area of Cultural Heritage } \\
\text { Site }\end{array}$ & Square meters & The larger the area, the higher the level of vulnerability. \\
& Number of objects & $\begin{array}{l}\text { Bilding types are divided into three, namely original, } \\
\text { modified, and rehabilitated. } \\
\text { Weight values (Rehabilitated: } 3 \text {, Modified: } 2, \\
\text { Original: 1) } \\
\text { The weight values were determined based on findings of } \\
\text { the field survey, i.e., rehabilitated temples tended to have } \\
\text { an intact structure from top to bottom. }\end{array}$ \\
\hline
\end{tabular}




\begin{tabular}{|c|c|c|c|}
\hline No. & Data & $\begin{array}{l}\text { Measurement } \\
\text { Units }\end{array}$ & Effects \\
\hline 3 & Structural integrity & Number of objects & $\begin{array}{l}\text { Structural integrity is differentiated into three, namely } \\
\text { complete, semi-complete, and incomplete } \\
\text { Weight values (Complete: } 3 \text {, Semi-complete: } 2 \text {, } \\
\text { Incomplete: 1) } \\
\text { More temples with complete structural integrity mean } \\
\text { higher vulnerability levels. }\end{array}$ \\
\hline 4 & $\begin{array}{l}\text { Number of Cultural } \\
\text { Heritage Objects }\end{array}$ & Number of Objects & $\begin{array}{l}\text { The higher the number of objects in the site, the higher } \\
\text { the vulnerability level. } \\
\text { Components: } \\
\text { Main Temples } \\
\text { Pervara (Complementary) Temples } \\
\text { Statues } \\
\text { Carving } \\
\text { Stupa/Ratna (mound-like structures containing relics) } \\
\text { Others }\end{array}$ \\
\hline
\end{tabular}

Table 5. Vulnerability Index generated by Multi-Criteria Evaluation

\begin{tabular}{lcccccc}
\hline \multicolumn{1}{c}{$\begin{array}{c}\text { Cultural } \\
\text { Heritage }\end{array}$} & Site Area & $\begin{array}{c}\text { Building } \\
\text { Type }\end{array}$ & $\begin{array}{c}\text { Structural } \\
\text { Integrity }\end{array}$ & $\begin{array}{c}\text { Number of } \\
\text { Objects }\end{array}$ & $\begin{array}{c}\text { Physical } \\
\text { Vulnerability } \\
\text { Index }\end{array}$ & $\begin{array}{c}\text { Vulnerability } \\
\text { Index of } \\
\text { Supporting } \\
\text { Facilities }\end{array}$ \\
\cline { 2 - 6 } Sewu & 0.60 & 0.45 & 0.25 & 0.606 & 0.77 & 0.017 \\
Bubrah & 0.03 & 0.50 & 0.33 & 0.093 & 0.47 & 0.003 \\
Lumbung & 0.05 & 0.37 & 0.20 & 0.026 & 0.52 & 0.002 \\
Prambanan & 1.00 & 0.48 & 0.29 & 1.000 & 0.95 & 1.000 \\
Gana & 0.01 & 1.00 & 1.00 & 0.003 & 0.15 & 0.003 \\
Ratu Boko Site & 0.66 & 0.44 & 0.29 & 0.012 & 0.63 & 0.039 \\
Ijo & 0.27 & 0.44 & 0.28 & 0.008 & 0.53 & 0.008 \\
\hline
\end{tabular}

Source: Data Analysis, 2019

Table 6. Social Vulnerability Index

\begin{tabular}{lccc}
\hline \multicolumn{1}{c}{ Cultural Heritage } & $\begin{array}{c}\text { Workers/Employees } \\
\text { Index }\end{array}$ & Visitor Index & $\begin{array}{c}\text { Social Vulnerability } \\
\text { Index }\end{array}$ \\
\hline Sewu Temple & 0.6818 & 0.1020 & 0.39 \\
Bubrah Temple & 0.6818 & 0.0198 & 0.35 \\
Lumbung Temple & 0.6818 & 0.0193 & 0.35 \\
Prambanan Temple & 1.0000 & 1.0000 & 1.00 \\
Gana Temple & 0.0545 & 0.0001 & 0.03 \\
Ratu Boko Site & 0.8818 & 0.1539 & 0.52 \\
Ijo Temple & 0.0818 & 0.0785 & 0.08 \\
\hline
\end{tabular}

Source: Data Analysis, 2019 
In addition to the two vulnerability indexes above, the social vulnerability of cultural heritage sites was analyzed using the number of employees and visitors. Here, social vulnerability refers to the potential of people at a cultural heritage site to be exposed to hazards. The higher the level of vulnerability, the higher the potential hazards threatening the existence of exposed lives within the observed area. As presented in Table 6, the highest social vulnerability level was found in Prambanan Temple (index=1), followed by the complex of Sewu, Bubrah, and Lumbung temples, with index values in the range of $0.35-0.52$. Prambanan is severely vulnerable to earthquake hazards and the secondary effects (landslides) because of the high number of individuals visiting or working at this site.

\subsection{Risk}

The outputs of the vulnerability index were processed as an input to the risk calculation. Based on Table 7, Prambanan Temple had a risk index of 0.90 and was thereby significantly at risk of damages in the earthquake hazard scenario with a 50-year return period. With a risk index of 0.36, Ijo appeared to be one of the temples at risk of landslides. Similar to the vulnerability index, the risk index values were quantified using a multi-criteria evaluation.

The risk index also functioned as a multiplier in the total valuation of the temple.
Total valuation, or otherwise known as significance value, is dependent on many factors. Based on the results of the interview with the head of the Prambanan unit office, the temple valuation techniques are broadly divided into four, namely economic valuation (e.g., travel cost method, tourism demand, the economic value of the site observed, and willingness to pay), land and facility valuation, temple component valuation, and intangible object valuation (including history, rarity, function, uniqueness, material condition, integrity, type of material, symbolic value, esthetics, and quantity). Significance value, however, could not be calculated in this research; hence, the valuation of the temples used a different approach that factored in the price, area, and volume of their constituent materials. Since there are a large number of temples in a cultural heritage complex, such as the Sewu Temple, this study was only able to assess one main temple that was still standing firmly and intact using the approach previously described.

Potential losses were calculated from the volume of the temple. For instance, the price of the andesite block sized 90x55×40 was multiplied by volume, area, and the risk index of the temple. Table 8 indicates the total cost of damage incurred on the object observed at Prambanan Temple, as an example of potential loss assessment due to earthquakes.

Table 7. Overall Risk Index of the Temples

\begin{tabular}{lccc}
\hline \multirow{2}{*}{ Cultural Heritage } & \multicolumn{3}{c}{ Risk Index } \\
\cline { 2 - 3 } & $\begin{array}{c}\text { Earthquake Hazards } \\
\text { Pe-Year Return } \\
\text { Period }\end{array}$ & $\begin{array}{c}\text { 50-Year Return } \\
\text { Period }\end{array}$ & $\begin{array}{c}\text { Landslide } \\
\text { Hazards }\end{array}$ \\
\hline Sewu Temple & 0.07 & 0.73 & 0.00 \\
Bubrah Temple & 0.05 & 0.44 & 0.00 \\
Lumbung Temple & 0.05 & 0.49 & 0.00 \\
Prambanan Temple & 0.10 & 0.90 & 0.00 \\
Gana Temple & 0.01 & 0.14 & 0.00 \\
Ratu Boko Site & 0.00 & 0.30 & 0.42 \\
Ijo Temple & 0.00 & 0.19 & 0.36 \\
\hline
\end{tabular}


Table 8. Potential loss assessment in case of earthquakes.

\begin{tabular}{|c|c|c|c|c|c|}
\hline \multirow{2}{*}{$\begin{array}{c}\text { Cultural } \\
\text { Heritage Sites }\end{array}$} & \multirow{2}{*}{$\begin{array}{c}\text { Cultural } \\
\text { Heritage } \\
\text { Temple }\end{array}$} & \multirow{2}{*}{$\begin{array}{l}\text { Volume } \\
\text { (m3) }\end{array}$} & \multirow{2}{*}{$\begin{array}{c}\text { Price of } \\
\text { Constituent } \\
\text { Materials* }\end{array}$} & \multicolumn{2}{|c|}{$\begin{array}{c}\text { Potential Losses Due to Earthquake } \\
\text { Hazards (IDR) }\end{array}$} \\
\hline & & & & $\begin{array}{l}\text { 10-Year Return } \\
\text { Period }\end{array}$ & $\begin{array}{c}\text { 50-Year Return } \\
\text { Period }\end{array}$ \\
\hline \multirow{6}{*}{$\begin{array}{l}\text { Prambanan } \\
\text { Temple }\end{array}$} & Wisnu & 4,006 & \multirow[t]{6}{*}{$18,480,000$} & $7,524,649,106$ & $66,807,632,245$ \\
\hline & Brahma & 3,388 & & $6,363,686,573$ & $56,500,020,977$ \\
\hline & Garuda & 1,113 & & $2,090,335,178$ & $18,559,050,649$ \\
\hline & Angsa & 1,122 & & $2,107,795,761$ & $18,714,074,518$ \\
\hline & Apit 1 & 271 & & $508,883,483$ & $4,518,124,380$ \\
\hline & Apit 2 & 300 & & $563,540,086$ & $5,003,393,287$ \\
\hline \multicolumn{2}{|c|}{ Total Potential Loss } & & & $19,158,890,1870$ & $170,102,296,056$ \\
\hline Ratu Boko Site & Pembakaran & $1,577.13$ & $18,480,000$ & $8,776,851,128$ & $12,302,280,870$ \\
\hline \multicolumn{2}{|c|}{ Total Potential Loss } & & & $8,776,851,128,00$ & $12,302,280,870$ \\
\hline \multirow{4}{*}{ Ijo Temple } & Pervara 1 & $36,236,186$ & \multirow[t]{4}{*}{$18,480,000$} & $129,187,859$ & $237,790,839$ \\
\hline & Pervara 2 & $56,069,301$ & & $199,896,119$ & $367,940,658$ \\
\hline & Pervara 3 & $44,397,922$ & & $158,285,767$ & $291,350,175$ \\
\hline & Main & $1,478.68$ & & $5,271,749,013$ & $9,703,494,062$ \\
\hline \multicolumn{2}{|c|}{ Total Potential Loss } & & & $5,759,118,758$ & $10,600,575,734$ \\
\hline
\end{tabular}

Notes: *the price of an andesite block sized 90x55x40 (15 blocks/m3; IDR1,232,000/block)

The total value of the constituent materials was the only applicable approach to quantify the potential economic loss of Prambanan Temple. Based on this value, the risk index was calculated and later functioned as a multiplier in assessing the overall risk of loss. In the earthquake hazard scenario with a 10-year return period, the impact on Prambanan Temple was estimated at IDR19,158,890,157, while in the 50-year hazard scenario, the economic loss might reach IDR170,102,296,056. These figures are most likely to increase because the quantification process did not incorporate all possible factors, implying that the potential loss assessment can still be modified according to what data are available for a cultural heritage site. Table 8 also explains that Ratu Boko Site was exposed to landslide hazard and might experience losses of up to IDR12,302,280,870. In the context of earthquake hazard with a 50year return period, the potential damage was worth IDR8,776,851,128. At the same time, Ijo Temple was also exposed to earthquakes with a 50-year return period, and the resulting damages were estimated at IDR5,271,749,013, with additional IDR10,600,575,734 due to the secondary effect, i.e., landslide.

\section{Conclusion}

This research has successfully identified potential losses by employing vulnerability and risk analyses for earthquake and landslide hazards. The integration of this information into InaRisk, however, poses a challenge in itself because the detailed information on potential losses applies uniquely to every object of the study but not regionally. Theoretically, the availability of more data that can support the valuation or significance value calculation of the temple is vital so as to increase the accuracy of the study results. In this study, potential losses are only based on the volume of the temple and the price of constituent rocks, while the valuation of cultural heritage sites has many aspects besides the physical condition of the building. Minimum data availability causes such calculation to rely solely on existing data. There are no standard provisions in determining the vulnerability of cultural heritage sites, so that defining and selecting variables that influence it are complicated. 


\section{References}

Amri, M. R., Yulianti, G., Yunus, R., Wiguna, S., W. Adi, A., Ichwana, A. N., \& Randongkir, Roling Evans Septian, R. T. (2018). RBI (Risiko Bencana Indonesia). In Bnpb Direktorat Pengurangan Risiko Bencana (Vol. 9, Issue 3).

BNPB. (2016). Info bencana. In Info Bencana: Informasi Kebencanaan Bulanan Teraktual.

BPS. (2020). Statistik Indonesia 2020 Statistical Yearbook of Indonesia 2020. Statistical Yearbook of Indonesia, April, 192.

Direktorat Pelestarian Cagar Budaya dan Permuseuman. (2016a). Prambanan. Retrieved from https://cagarbudaya.kemdikbud.go.id/public/objek/detailcb/PO2015071300004/prambanan

Direktorat Pelestarian Cagar Budaya dan Permuseuman. (2016b). Rekap Tahunan Cagar Budaya.

Hizbaron, D. R., Hadmoko, D. S., Mei, E. T. W., Murti, S. H., Laksani, M. R. T., Tiyansyah, A. F., ... Tampubolon, I. E. (2018). Towards measurable resilience: Mapping the vulnerability of at-risk community at Kelud Volcano, Indonesia. Applied Geography, 97(June), 212-227. https:// doi.org/10.1016/j.apgeog.2018.06.012

ICCROM; ICOMOS; IUCN; UNESCO World Heritage Centre. (2010). Managing Disaster Risk for World Heritage. Paris: United Nations Educational, Scientific and Cultural Organization. https://whc.unesco.org/en/managing-disaster-risks/

Iqbal, D. (2018). Mitigasi Bencana, Jangan Lagi Dipandang Sebelah Mata. https:/ / www.mongabay.co.id/2018/10/23/mitigasi-bencana-jangan-lagi-dipandang-sebelah-mata/

Kusuma, W. (2016). Gempa Bumi 2006 Porak-porandakan Kompleks Candi Prambanan. Retrieved from https://regional.kompas.com/read/2016/05/27/08300061/gempa.bumi.2006.porak-porandakan.kompleks.candi.prambanan?page=all

Marrion, C. E. (2016). More effectively addressing fire/disaster challenges to protect our cultural heritage. Journal of Cultural Heritage, 20(Cultural HELP 2014 Special Issue), 746-749.

Marchezini, V., Iwama, A. Y., Pereira, D. C., Conceiçāo, R. S., Trajber, R., \& Olivato, D. (2020). Designing a Cultural Heritage Articulated Warning System (CHAWS) strategy to improve disaster risk preparedness in Brazil. Disaster Prevention and Management, 20(DOI 10.1108/ DPM-07-2018-0227), 65-85.

National Library of Indonesia. (2014). Temples of Indonesia. https://candi.perpusnas.go.id/ temples_en/deskripsi-about_temple

Parisi, F., \& Augenti, N. (2013). Earthquake damages to cultural heritage constructions and simplified assessment of artworks. Engineering Failure Analysis, 34, 735-760.

PT. Taman Wisata Candi Borobudur Prambanan Ratu Boko. (2019). Mengenang Peristiwa Gempa Bumi 27 Mei. Retrieved from http://bumn.go.id/borobudur/berita/1-Mengenang-Peristiwa-Gempa-Bumi-27-Mei

Rico, T. (2014). The limits of a heritage at risk framework: the construction of post disaster cultural heritage in Banda Aceh, Indonesia. Journal of Social Archaeology, 14(2), 157-176.

Romāo, X., \& Paupério, E. (2019). An Indicator for Post-disaster Economic Loss Valuation of Impacts on Cultural Heritage. International Journal of Architectural Heritage: Conservation, Analysis and Restoration(https://doi.org/10.1080/15583058.2019.1643948), 1-20.

Spennemann, D. H., \& Graham, K. (2007). The importance of heritage preservation in natural disaster situations. International Journal Risk Assessment and Management, 7(6/7), 993-1001. 
UNISDR. (2009). UNISDR Terminology on Disaster Risk Reduction. https://www.undrr.org/ publication/2009-unisdr-terminology-disaster-risk-reduction. Geneva: UNISDR.

Wang, J.-J. (2015). Flood risk maps to cultural heritage: measures and process. Journal of Cultural Heritage, 16, 210-220. 